\title{
الرموز الثعبية ودورها في اعمال النحت الخزفي.
}

قسم التربية الفنية

قسم التربية الفنية
كلية التربية الأساسية

كلية التربية الأساسية التربية
د. د. محمد محمد صلاح درويش

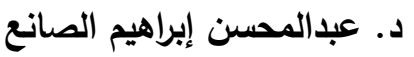

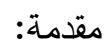

"يعتبر الرمز من أهم عناصر التراث الشعبي فهو موجود في معنى ومضمون وموضوع أي عمل تثكيلي شعبي، فنادراً

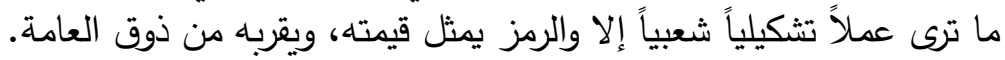

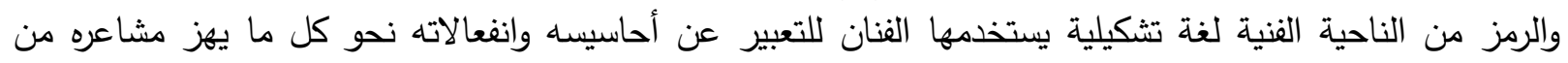

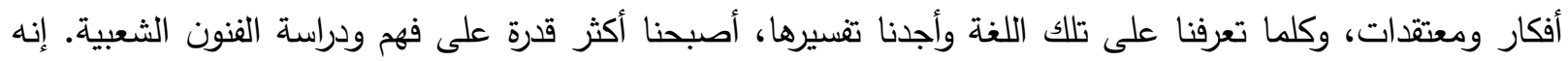

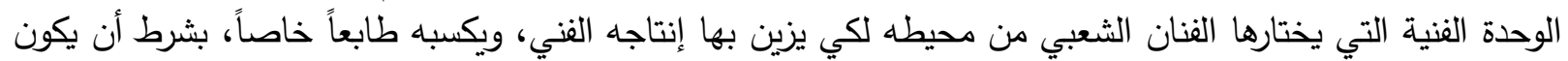

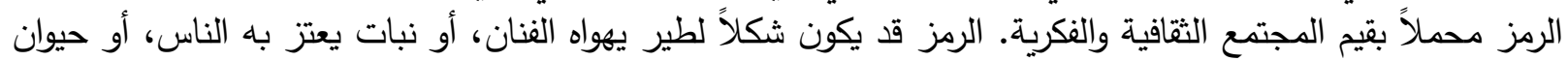

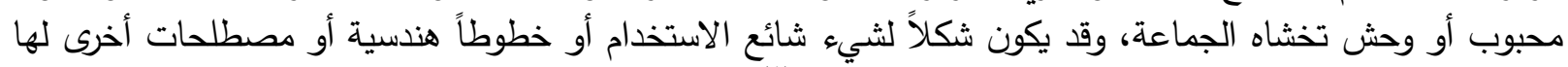

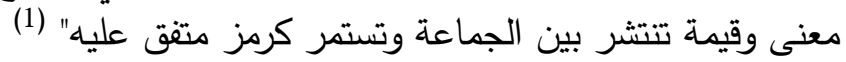

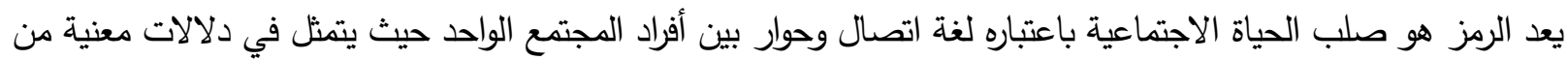

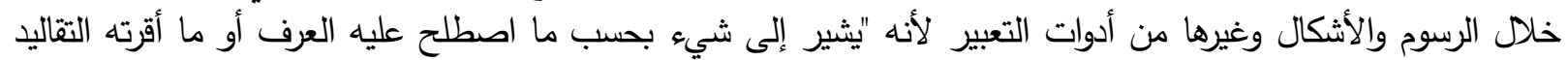

منذ زمن بعيد" (2) والفنان الثعبي يعبر أثز ما يعبر عن قضايا حيوية واحتياجات هي متطلبات المجتمع وغاية مقاصده بطريقة سهلة وبسيطة، يكثف فيها عن هدف يتجه إلى تحقيقه مشكلة البحث:

تناول البحث مختارات من التراث الثعبي "عناصر ورموز" وإيضاح أثرها في التشكيل النحتي لهيئات زخرفية معاصرة، بما تتضمنه من قيم جمالية نابعة من البيئة المحيطة بالفنان والتي يمكن من خلالها تحان تحقيق هيئات نحتية مبتكر بأشكال

مختلفة.

$$
\text { نجد مشكلة البحث تنحصر لاينا في عدة تساؤلات: }
$$

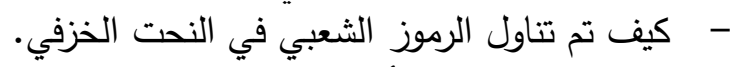

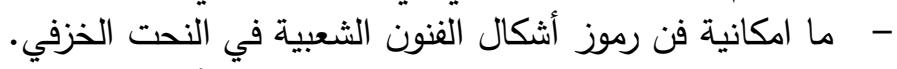

أهمية البحيث: مدى قدرة استيعاب فن النحت الخزفي لأشكال الرموز الشعبي.

تكمن في : - دور الرموز الثعبي في النحت الخزفي.

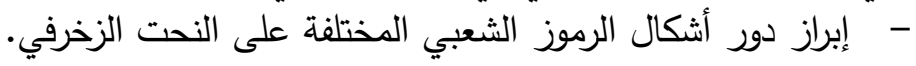

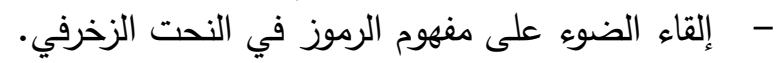
- الهدف من البحن الأبحاث السابقة والدراسات المرتبطة في هذا المجال عما حاول الوصول إليه هذا البحث.

- - إلقاء الضوء على العوامل التي أدت إلى تتوع أشكال الرموز التي نهجها الفنان.

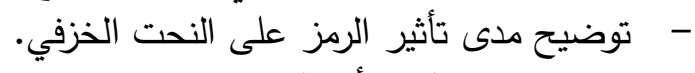

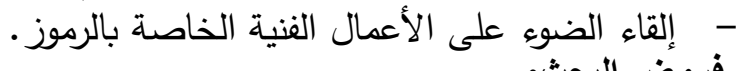

فروض البحث:

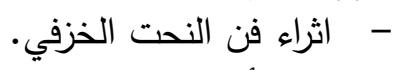

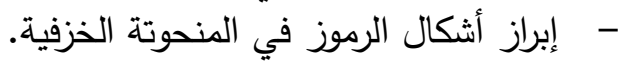

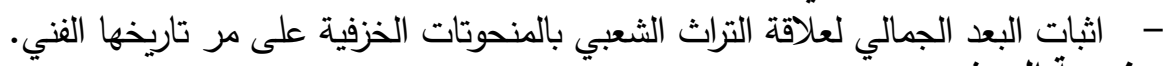
منهجية البحث:

للوصول إلى تحقيق هدف البحث المنهج الوصفي والتحليلي لبعض نماذج وأعمال النحت الخزفي.

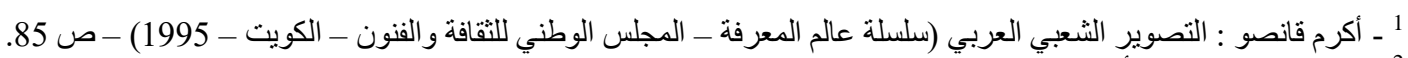

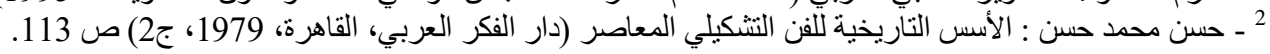




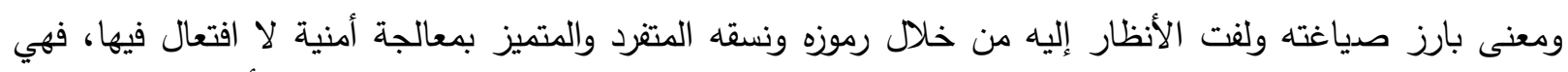

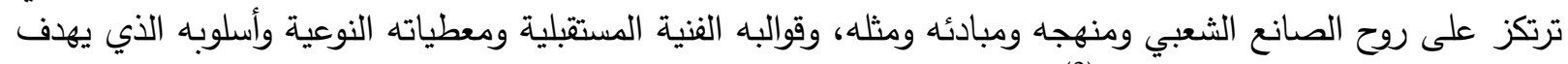

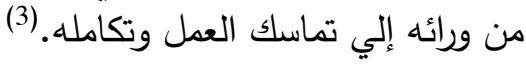

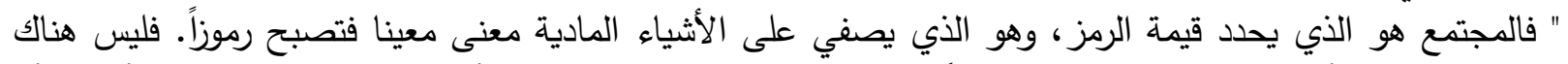

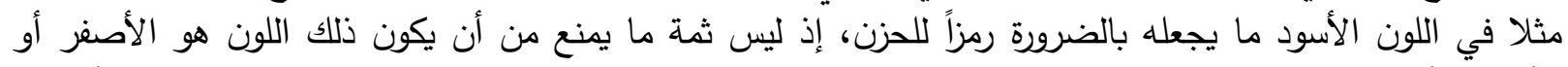

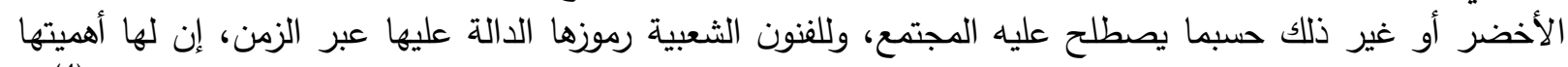

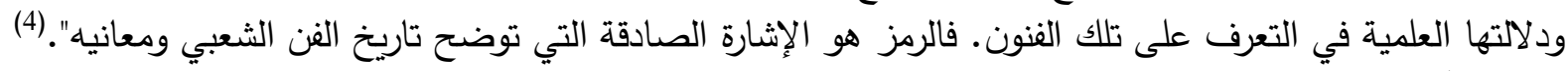
1

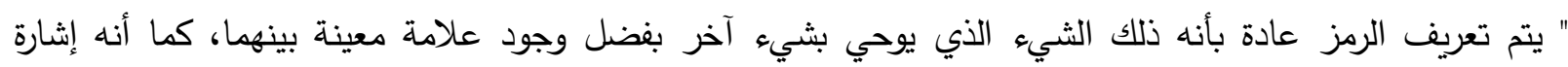

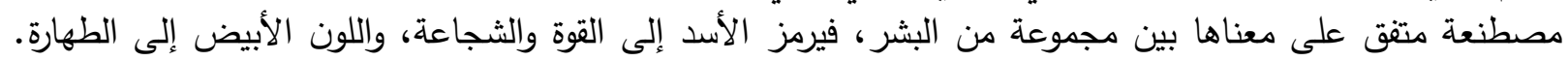

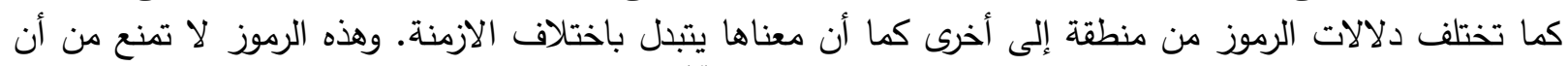

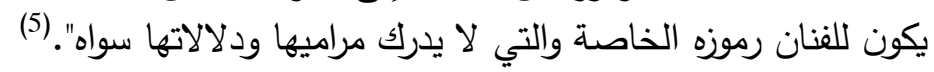
كما تم تعريفه بأنه "كل ما يحل محل شلفيء الخداه آخر في الدلالة عليه، لا بطريق المطابقة التامة وإنما بالإيحاء أو بوجود

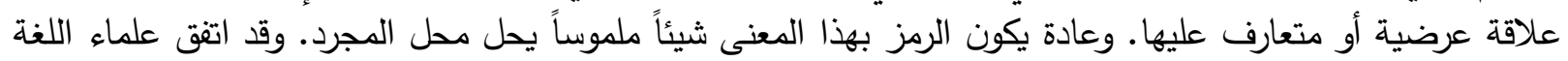

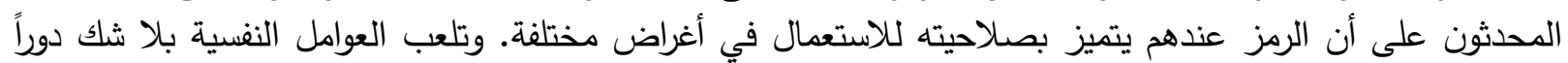
هاماً في تحديد دلالته. ونجد مأ يماثل ذلك في قاموس Shorter Oxford Dictionary الذي دئه يعرف الرمز بانه ما يدل على شيء غير ذاته،

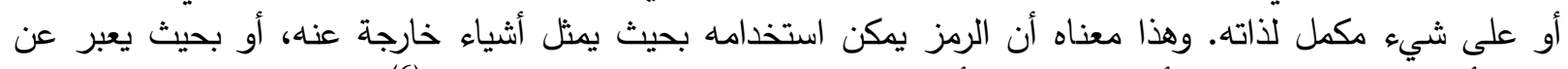

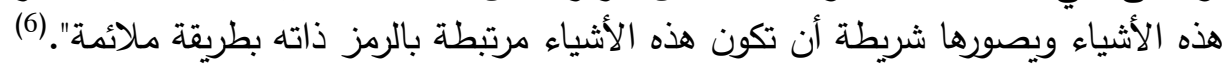

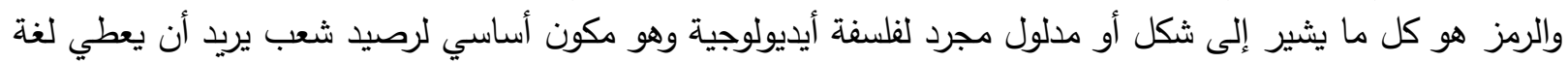

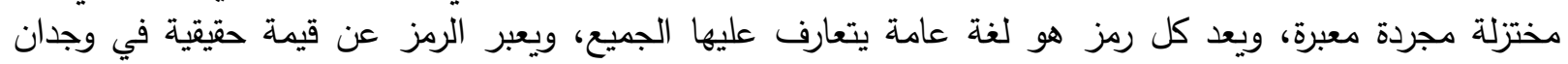

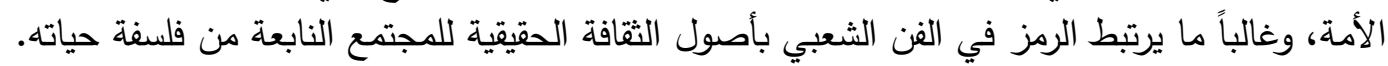

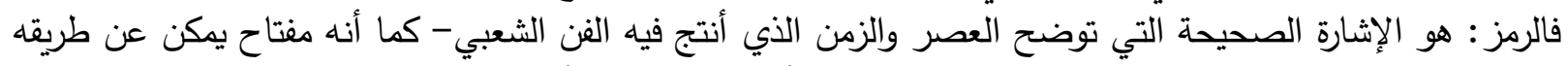

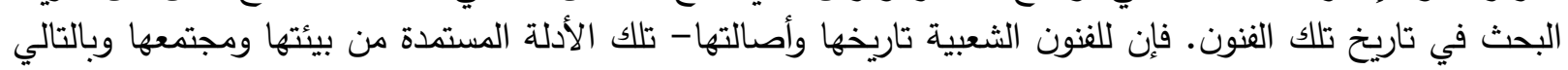
من حياة الثعوب وكفاحها.

$$
\text { الرمز في الفن الثعبي: }
$$

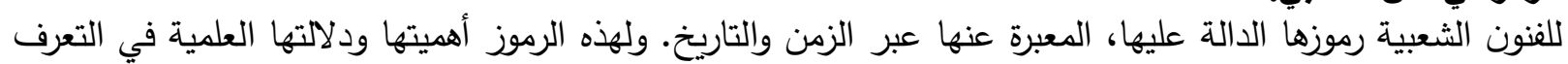

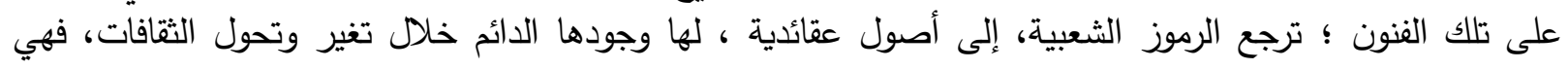

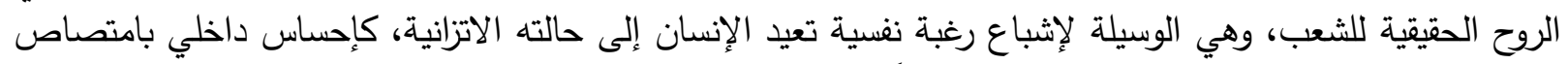

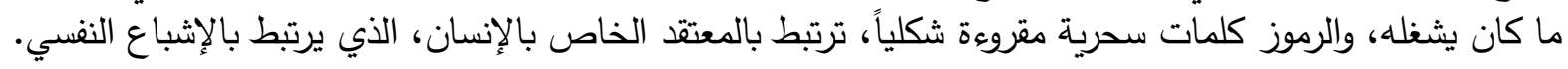

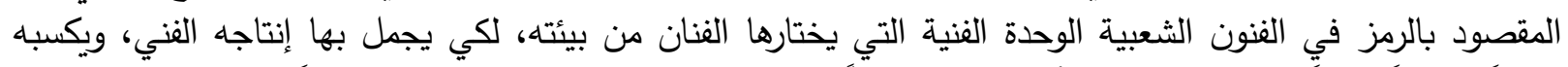

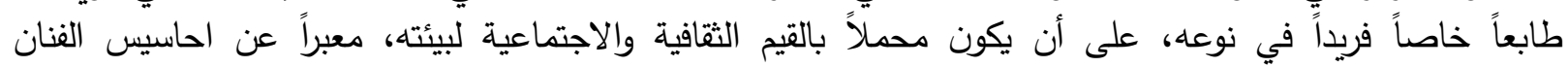

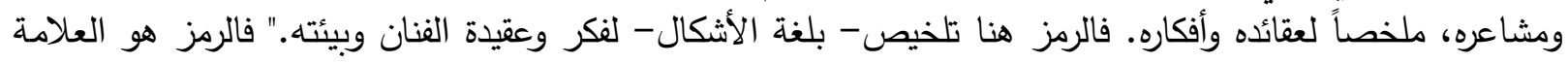

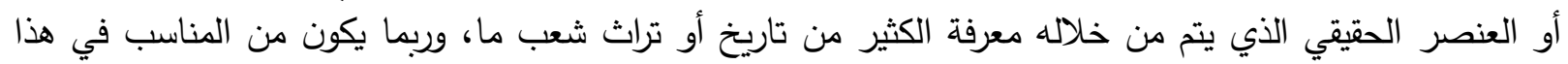

3ـ ــ كمود النبوي الثنال: الفنون الثعبية التنكيلية (الهيئة المصرية العامة للكتابـ مجلة الفنون الثنعبيةـ العدد 26- 1989)- ص 12.

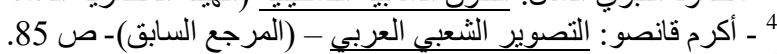
5 ـ ـ صبري منصور: الرمزية في الفن الحديث (وزارة الإعلام - عالم الفكر، المجلد السادس عشر - العدد الثالث، 1985، الكويت) - ص 136-137، بتصرف 6 ـ ـ أحمد أبو زيد: الرمز و الأسطورة والبناء الاجتماعي (عالم الفكر، المجلد السادس عشر - العدد الثالث، 1985، وزارة الإعلام، الكويت) ص 5-6، 
الصدد ذكر بعض الرموز أو الأشكال الرمزية التي اتخذتها الجماعة الشعبية في مصر كعناصر دالة على مفاهيم

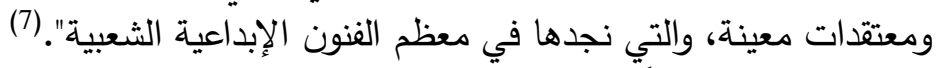

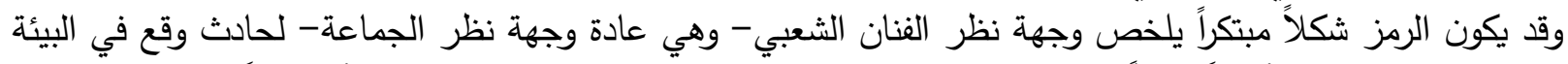

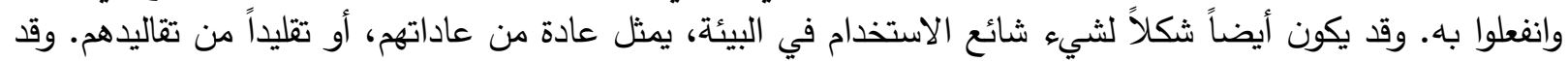

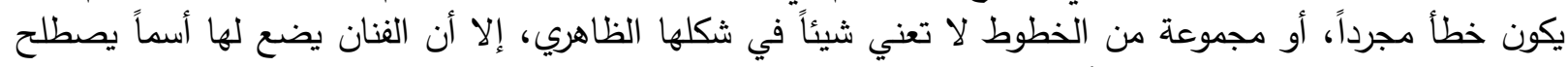

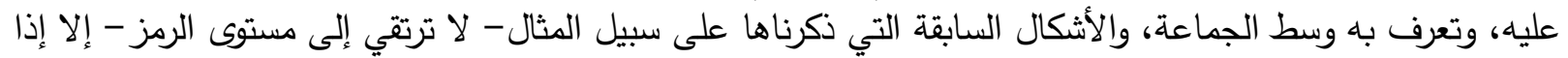

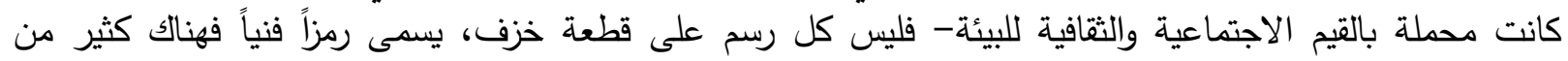
الرسوم والوحدات الزخرفية التي تحمل القيم الثقافية الثعبية. لهذا تحتاج "الوحدة الفنية" إلى فترة طويلة من الزمن حتى حتى تثبت قيمتها وسط بيئتها وبالتالي تتداول- كاللغة- وهنا

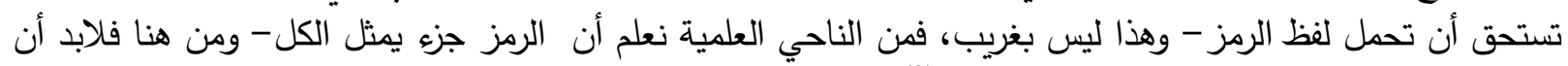

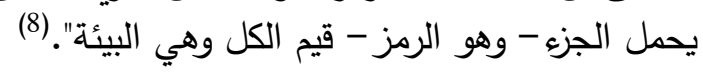

كما نلاحظ أن للطبيعة وعناصرها دور كبير في انتاج الرموز الشعبية "فالطبيعة والإنسان مرتبطان منذ بدء الخدان الخليقة

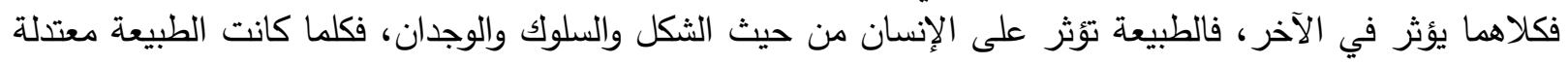

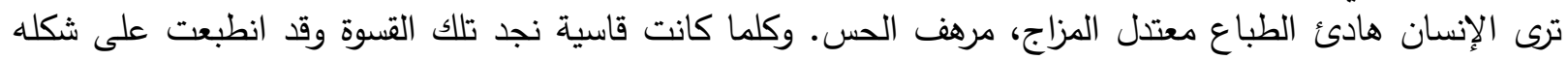
وسلوكه. كذلك الإنسان يتأقلم مع الطبيعة ويستخل إمكانياتها ويسخرها لخدمته قدر استطاعته، هذا بالنسبة للطبيعة

المادية للبيئة". (9)

"إإذا تتبعنا الأثر العميق للرموز الطبيعية في التراث الإنساني، لأدركنا الدور الهام الذي لعبته العناصر الرمزية

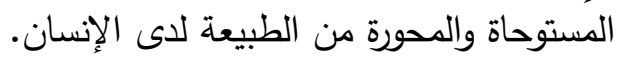

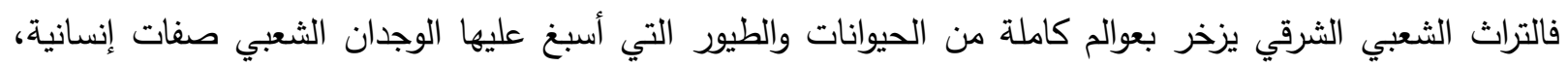

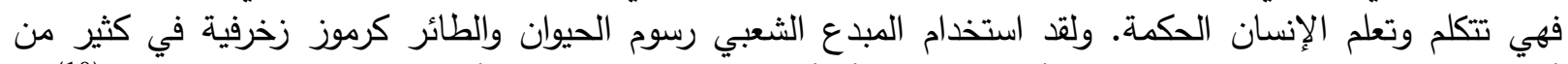

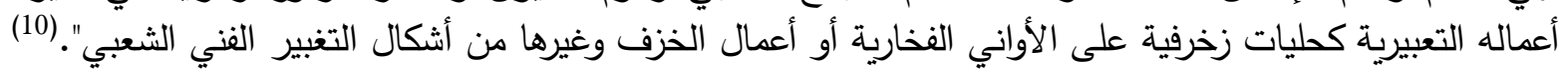
وهكذا لو تتاولنا الرموز الشعبية بالدراسة والبحث لوجدنا أن كل رمز لله امتداده وجذوره البعيدة العميقة في حياة الناس، وتكون الرموز إما مجردة أو شكلية.

فالرموز المجردة مثل الهلا، والصليب، والدائرة، والمثلث، والسهم، والعين... إلخ.

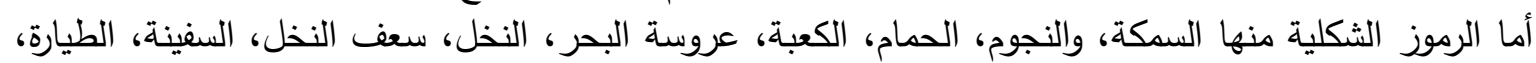
الجمل، الإبريق، الزهرية، المحمل......إلخ. وقد تكون الرموز مباشرة واضحة يمكن فهمها وإدراكها وقد تأخذ شكلاً مجرداً يحتاج إلى تفسير وتأويل مثل المثلثات

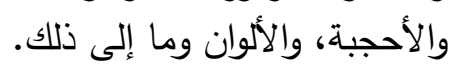
ولكي نميز ونتذوق أي عمل فني تشكيلي من خلال الفنون الشعبية، فلابد لنا من امتلاك مفاتيح اللغة التشكيلية التي

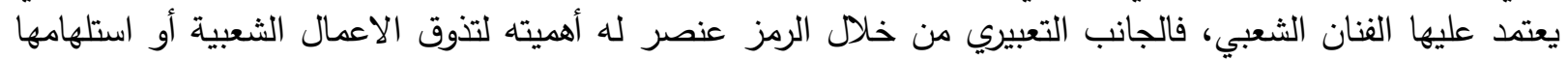
من قبل المثقين. " يتمتع الرمز في التعبير الشعبي بخاصية المرونة، فنجد رموزا شعبية قد لا تتغير وظيفتها وشكلها على مدى العصور .

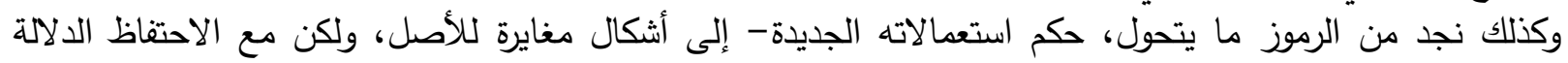

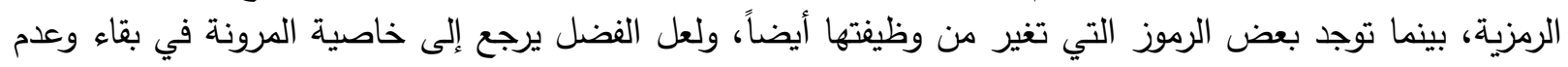

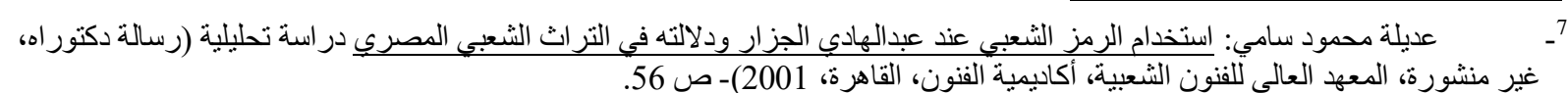
8. حسين على الثريف: الرمز في الفن الثعبى التثكيلي (مجلة الفنون الثعبية، الثقافية، والإرشاد القومي العدد الثاني- ابريل 1965) - ص 96- 98،

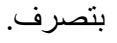

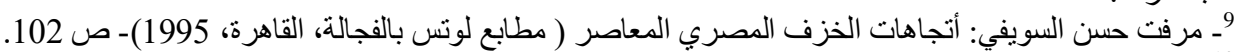

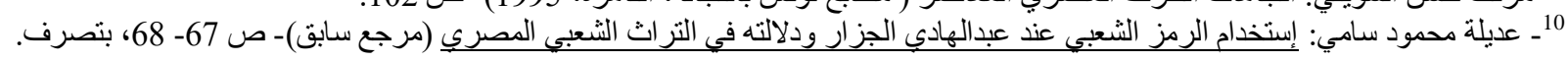




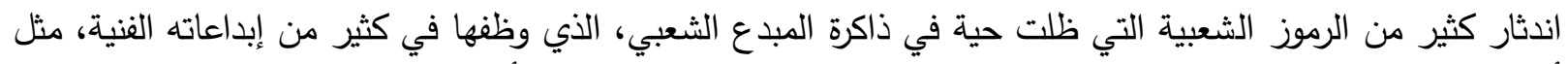
أعمال الفخار والنحت الخزفي وغيرها من الصناعات والفنون التشكيلية الثعبية الأخرى.

واحتفاظ المبدع الشعبي بهذه الرموز كأثكال في ذاكرته لا يعني بأي حال من الأحوال أنه على وعي بأصلها وجذورها

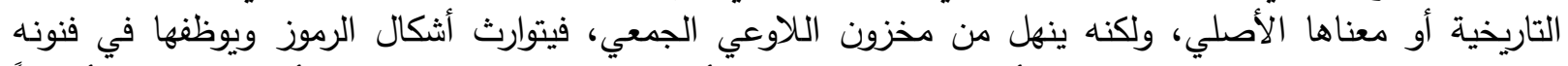

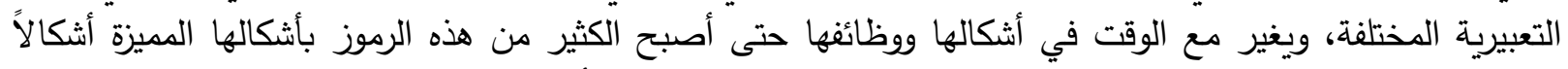
وموتيفات زخرفية تشكل عناصر هامة في فنونه الشعبية التي توارثها عن الأجداد.

لذلك فإن دراسة الرموز الشعبية والوصول إلى جذورها في التراث الشعبي وأصل استعمالاتها قديماً قد يتطلب إخضاعها

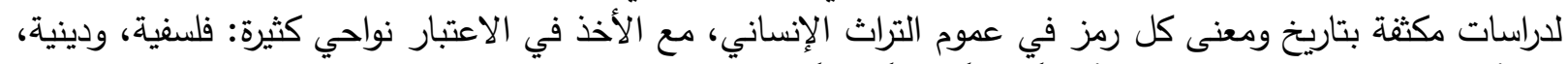

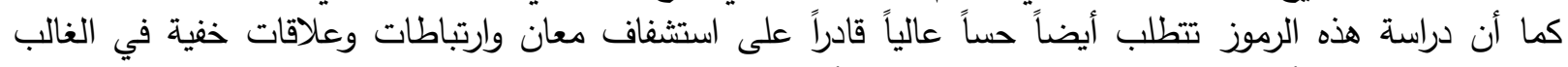

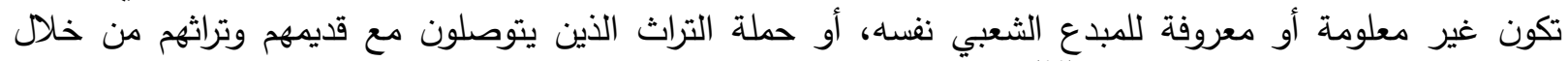
الموروثات بدون تدخل للعقل الواعي". (11)

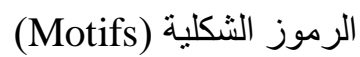
أشكال الآدمية:

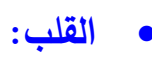

يعد القلب هو المعبر عن الوجه الثاني للإنسان، وذلك لما يحويه في جوانبه من عواطف وضمير وأخلاقيات، كما أنه الفه قد يختلف بكل الصور إلى الثر والضرر وسوء النوائ.

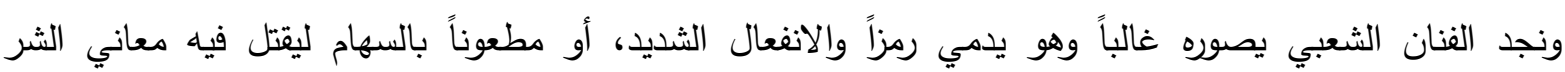
والإيذاء، وهو يتصور في ذات الوقت أنه يقتل ابليس أو الثيطان في رمز يران ئفال في قلب الإنسان.

• الكف:

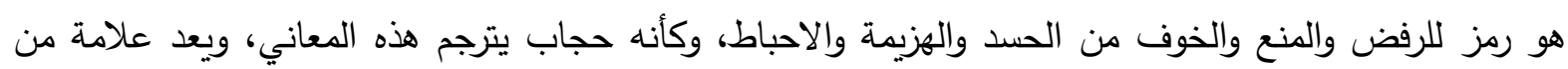

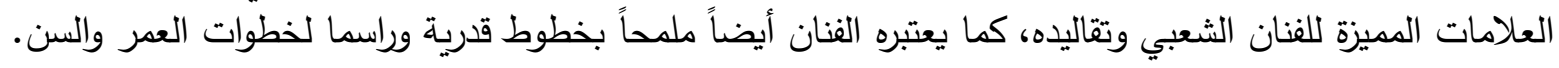

اعتبر الفنان الثعبي العين رمزاً لمراكز الحسد والإيذاء والثر، وهي النافذة التي يطل منها الشيطان على المرئيات فيصيبها بالأنى ويحقق فيها مآربه القاتلة.

ولهذا نجده يصورها وقد أخترقها سهما ليحبط فيها هذه المعاني ويقلل من تأثيرها الضار .

الأشكال الحيو انية و الطبيعية

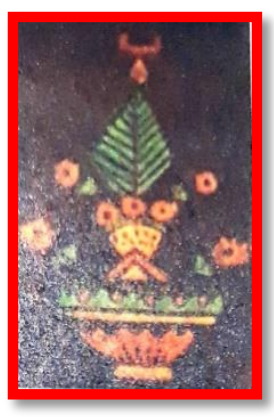
النبات:

سواء كان رسماً طبيعياً للنبات، أو على شكل محور إلى مجموعة من المثلثات، فهي رمزاً للرزق والخير الممتد.

11 ــ عديلة محمود سامي: استخدام الرمز الثعبي عند عبدالهادي الجزار ودلالته في التراث الثعبي المصري(مرجع السابق)- ص 61-63، 


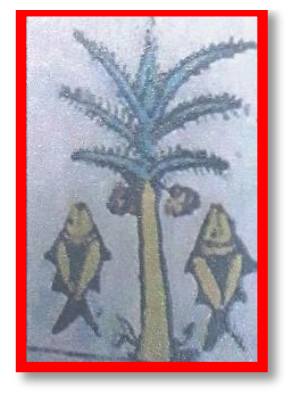

• • (النخلة: -

رآها الفنان الشعبي كامرأه مثمرة، ورمز بها للعطاء، والنخيل رمزا ذا معان متأصلة في المعتقدات الثعبية منذ القدم فهي ترمز للازدهار والخصب والإنتاج الوفير .

وهو رمز للارتقاء والسمو والإطلال، وتعني صفاء الإنسان المتصف بها وتألقه، كما تعني التميز والإبهار .

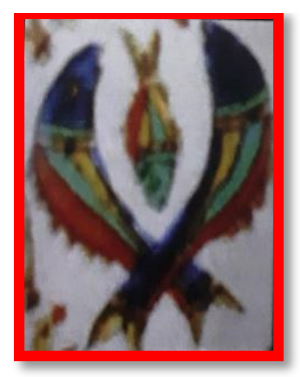

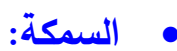

هي رمز الحركة والبحث عن الروق، كما ترمز للخير والبركة، والفنان الشعبي

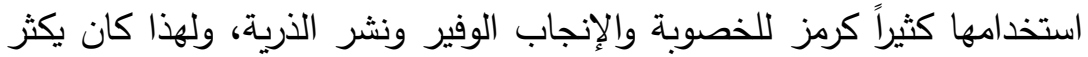

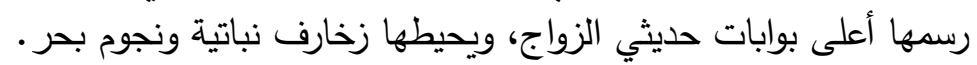

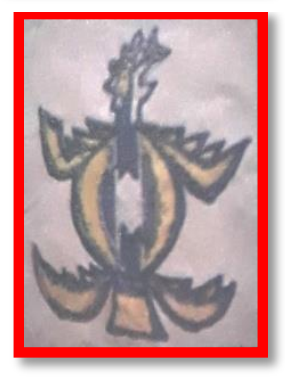

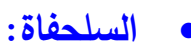

ترمز إلى الني والحكمة والتمهل وعدم التسرع وجلب الخير في المكان، ولمح

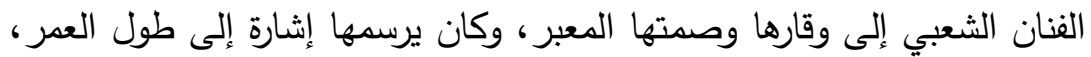

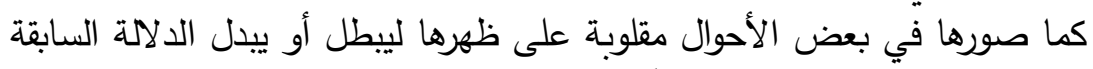

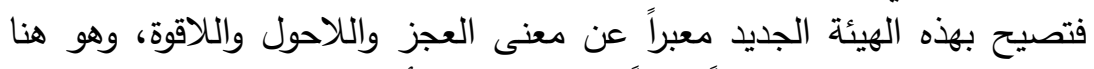

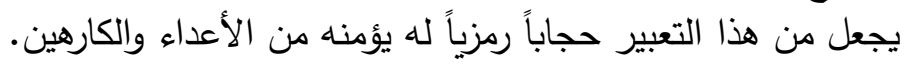

وهو رمز للشر المبيت في الخفاء، فهو يظهر فجأة ويضر فجأة ورآه الفنان الشعبي رمزاً لشيطان الإنسان وأسوأ العباد

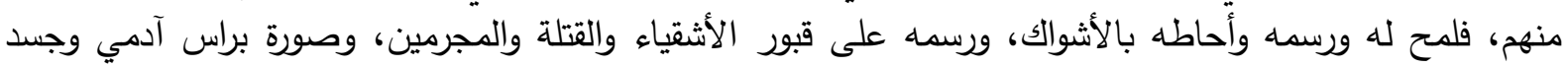

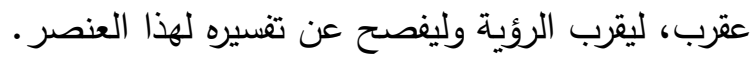

ويطول المطاف حول أسطورة العقرب فنجد أن الإنسان البدائي قد لجأ لعبادته لتجنب شره، وفي النوبة المصرية نجده

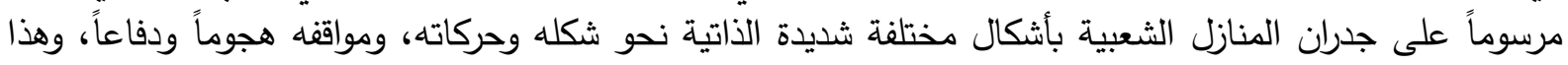

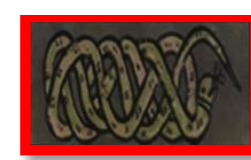

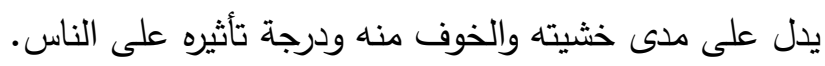

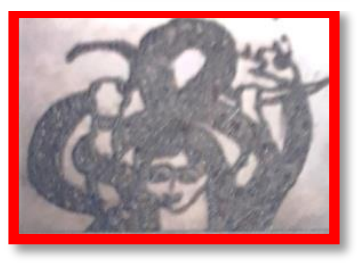

رمز إليهما بالضرر غير المتوقع رغم ملمسهما الناعم، فهما يمثلان لاى الفنان

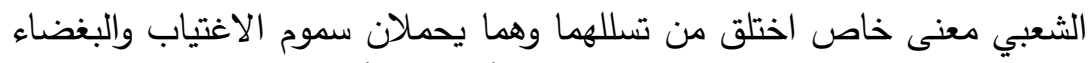

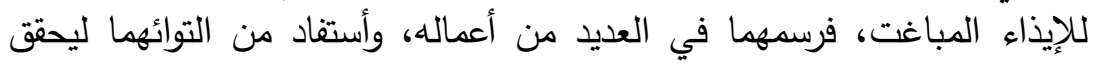

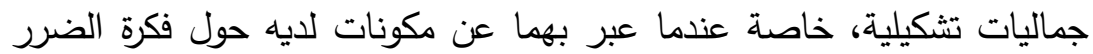
بالآخر - 


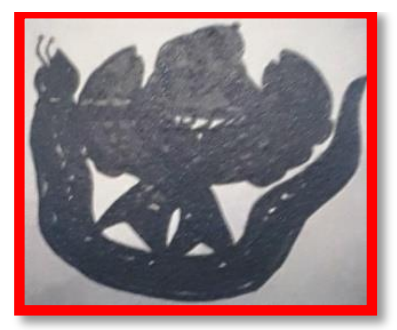

وتعد الأفعى أيضاً رمزاً للشيطان والكراهية والعدو، وهذا نظراً لتوحدها بالشيطان حين تسلل إبليس إلى الجنة داخلها ليغوي آدم وحواء.

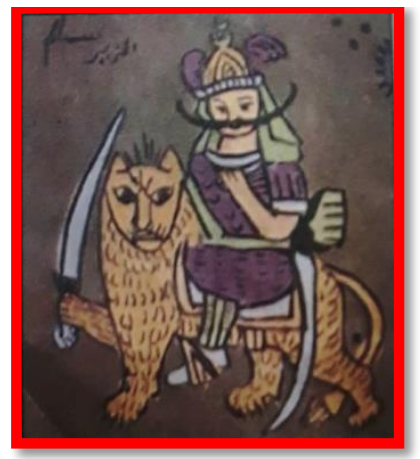

• • تؤكد الأسدر:

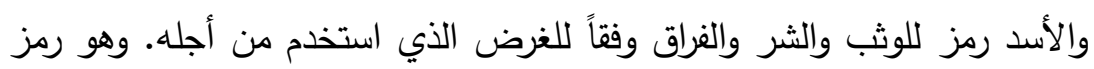

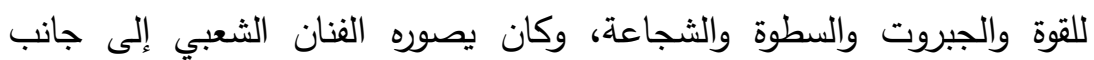

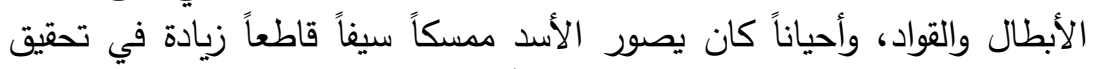

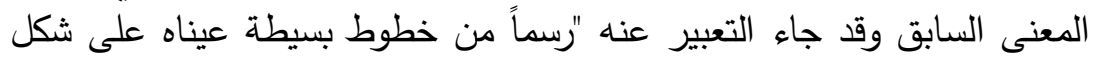

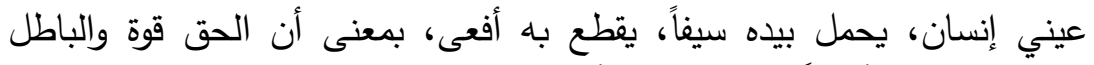

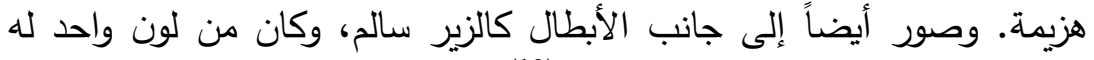

رأس بشري، خال من التفاصيل الدقيقة" (12)

يراه الفنان الشعبي رمزاً للفأل الحسن وحلول البركة، وطارداً للشيطان والثرور والغضب، كما رآ كذلك المصريين القدماء بنفس المعنى، وجعلوه معبراً عن كل شلك في تعاويذهم ورسومهم، وهو أيضاً يحقق السعادة والبشرى.

على الرغم من أنها رمزاً للحكمة عند اليونانيين، إلا أنها شكلت عكس ذلك عن الفنان الشعبي المصري، فنظرا لهجرتها

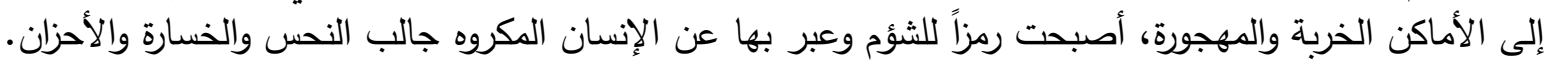

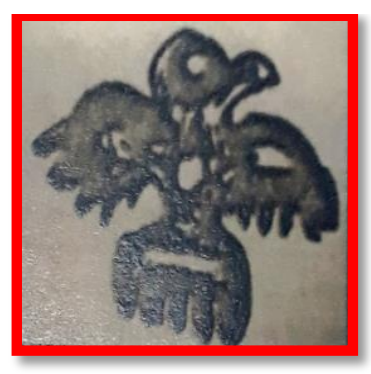

سمي في الفن الثعبي بـ (غراب البين) أي غراب الخيبة والثؤم وسوء الأخبار، وموضع البلاء وجلب المشاكل.

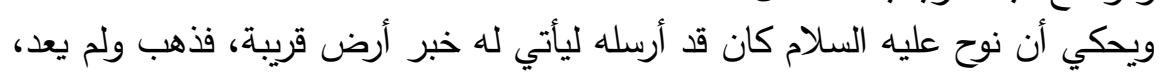

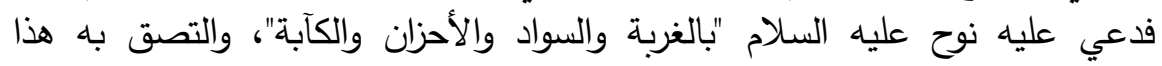
الدعاء حتى اليوم، فانقلب من وقتها لونه من الأبيض إلى الى الى الأسود.

الحمامة:

اعتبرها الفنان الشعبي رمزاً للسلام من سياق قصة سيدنا نوح عليه السلام، عندما

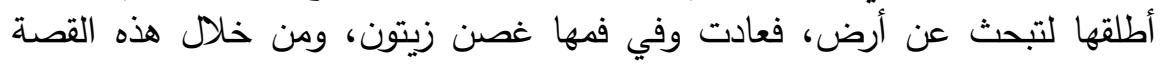

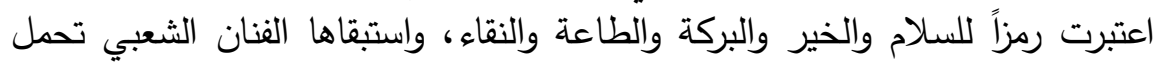

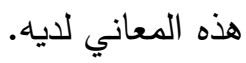

12 ـ أكرم قانصو: التصوير الثُبي العربي (مرجع سابق) - ص 87. 


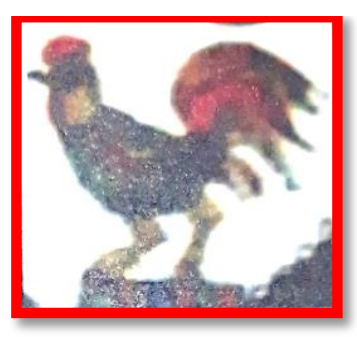

هو طائر داجن، له وضعه ومكانته عند الفنان الشعبي، وهو يرمز لانبلاج الفجر

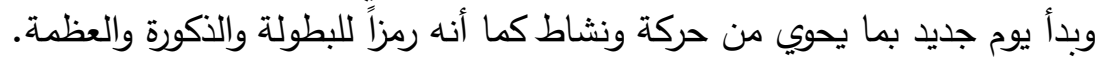

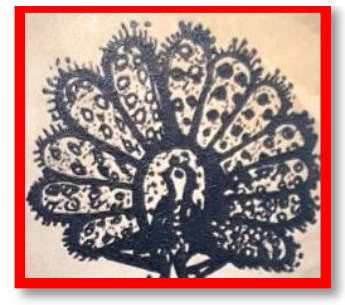

$$
\text { • الطاووس: }
$$

رمز الحظ السعيد وقد استخدم كثيراً في العصر الإسلامي والقبطي بألوان زاهية وعلق في غرف العرسان.

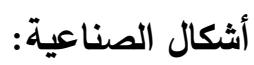

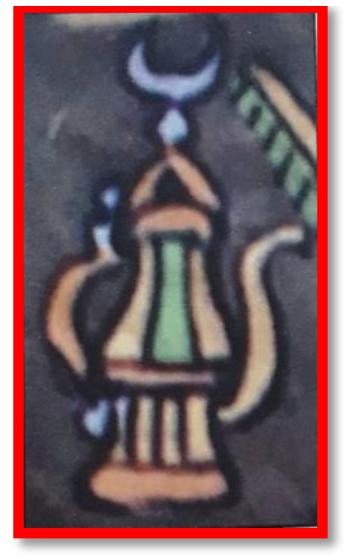

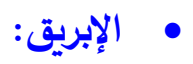

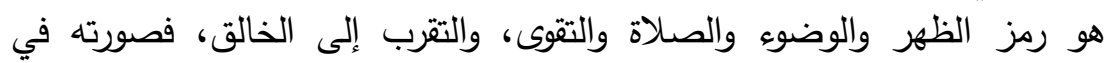

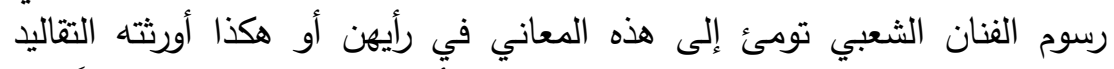

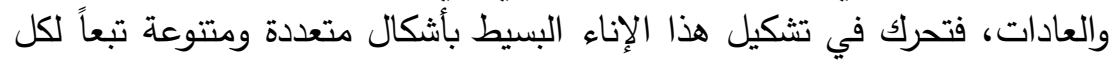

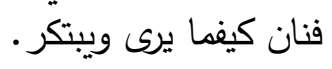

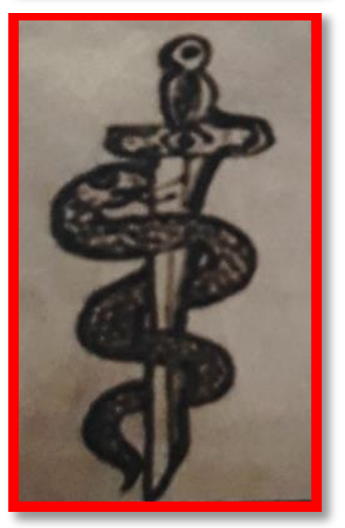

• السيف:

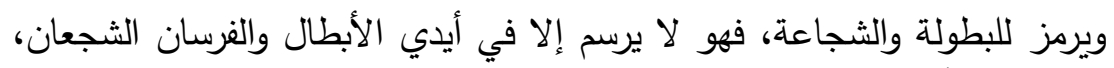

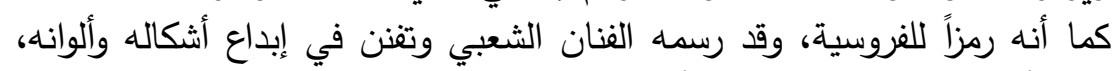

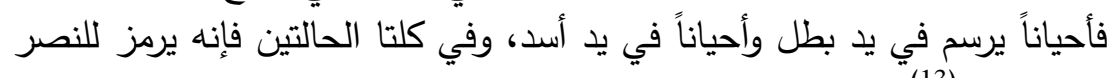

والشجاعة" (13)

أشكال الهندسية : لم تقتصر الرموز في التراث الثعبي على الصور الواضحة، بل شملت الأشكال الهندسية والعناصر المجردة بأنواعها المتعددة، فكان لها جميعاً في الوسط لشعبي معان في ودلانلات:

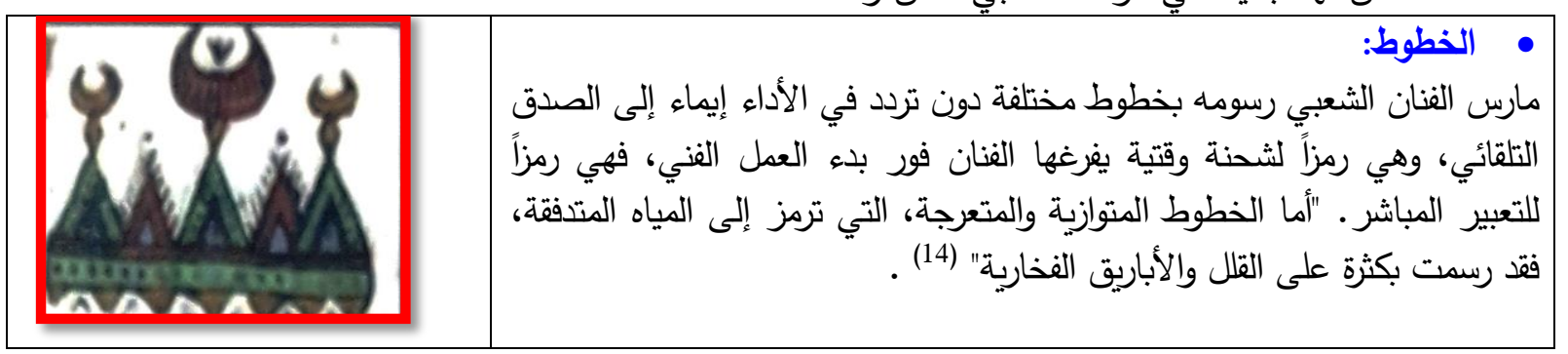

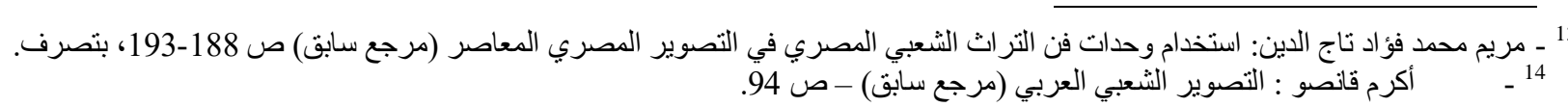


"كما رسمت الأشكال الهندية (المثلث والمربع والدائرة) متداخلة ومتقرقة، للتعبير عن دلالات سحرية وطلاسم نشاهدها بكثرة

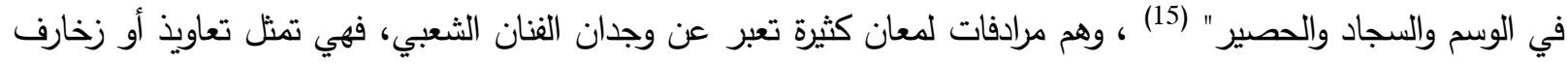

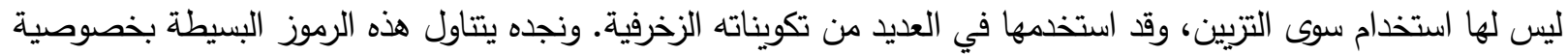

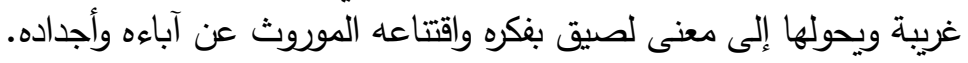

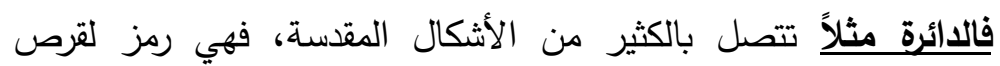

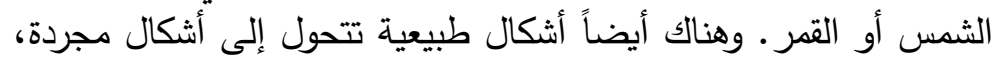

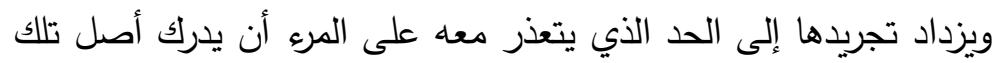

$$
\text { الرموز • فرمز العين الواقية }
$$

اتخذ شكل الخطوط المتكسرة، واستخدم في النسيج والمصاغ المشئ المشغولات الخشبية. واتخذ شكل المربعين المتقاطعين وشكل المثلث أحياناً. كذلك بالنسبة لرمز الكف وانف نجد أنه يتحول تباعاً إلى خطوط هندسية عددها خمسة.

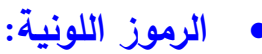
يلعب اللون دوراً أساسياً في الفنون الثعبية. فتلك الفنون تتميز ألوانها الفطرية الأولية، "ولا يخضع استخدام اللون

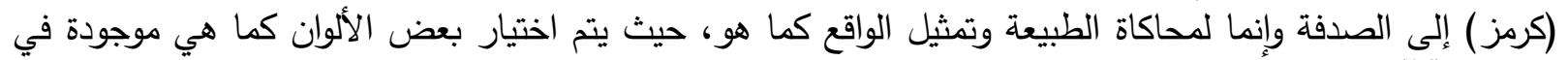

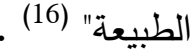
"ومع أن لكل بيئة رموزها، إلا أنها تتفق جميعها في فطرية اللون: فالأحمر ، والأصفر ، والبرتقالي، والأسود، والأبيض،

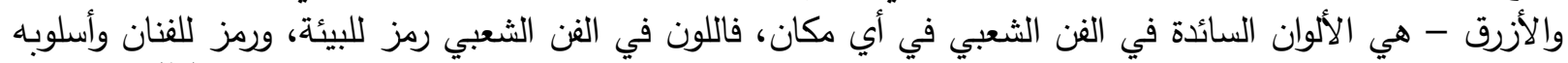

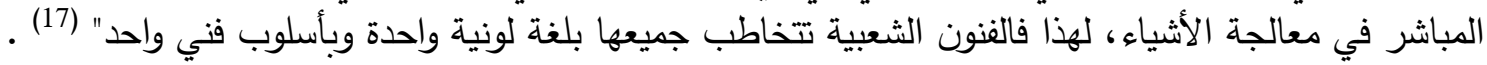
"وقد استخدم الفنان الثعبي المصري ألواناً تحمل دلالات رمزية وتفسيرات معروفة لديه، ولها تأثيرها النفسي على الفي المشاهد، متأثراً بأفكاره العقائدية الثعبية المتوارثة ونذكر منها: •

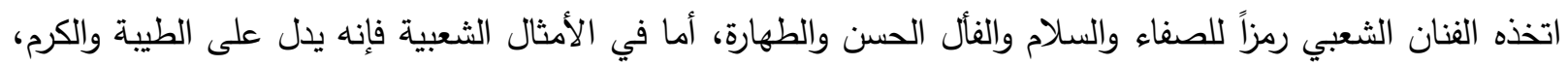
ولهذا نجده مستخدم بكثرة على جدرتن المنازل النوبية والفخار على شكل نقوش ووحدات زخرفية.

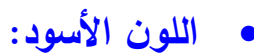
وهو رمز للحزن والموت والعسر والضيق والثؤم، ويرمز للخطايا والمعاصي، وقد لون به الفنان الشعبي البوم والغربان ورموز الشر جميعاً.

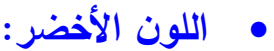
يعد اللون الأخضر رمزاً للخير والإيمان، فهو بلون النبات والخضرة المثمرة التي هي عماد حياتهم، فهو بذلك من الألوان المحببة لدى المصريين حيث يدعو للتفاؤل.

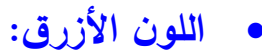

ويرمز للمكر، فيقول فلان نابه أزرق أي أنه خبيث ماكر شديد الضراوة والضرر، وكثيراً ما يطلق عليه الثعبيين أخضراً خاصة

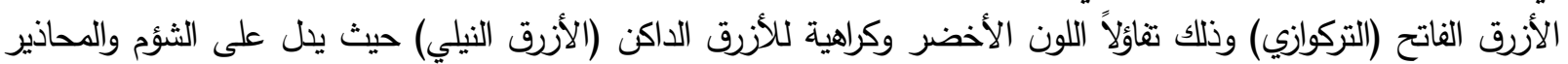
والفأل السيء والحزن.

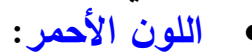

ويرمز للحب والخطر والدم وأحياناً الموت، وهو يمثل في المعتقد الشعبي الثر والكثر وأحياناً يعبر عن الأفراح الأعياد.

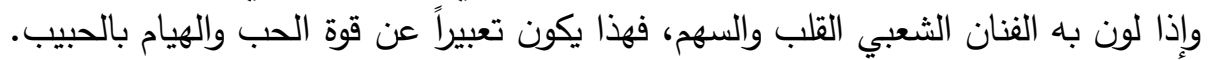

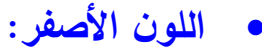


"يعد رمزاً للخبث، فيصفون الثخص الخبيث أن ضحكته سفراء، كما يرمز اللون الأصفر للمرض. وقد استخدم الفنان

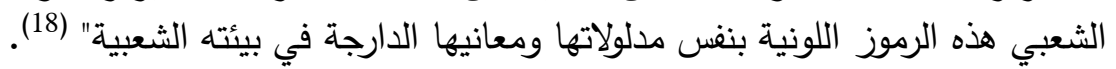

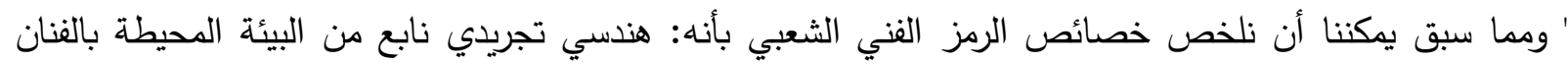

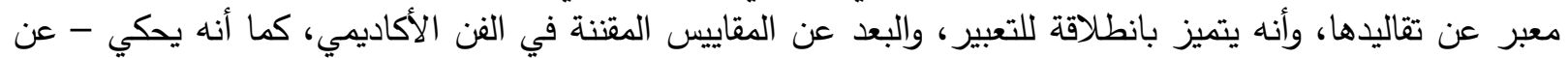

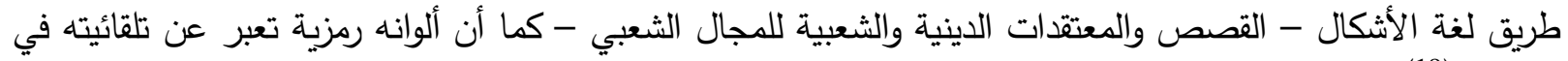

التعبير" (19)

- الرموز الثعبية المستخدمة في المنحوتات الثعبية: من الفنون الإنتاجية، التي تلعب في تشكيلها الحاسة دوراً حيوياً، فن الفخار حيث يعد فن الفخار من الفنون التراثية التي التيات

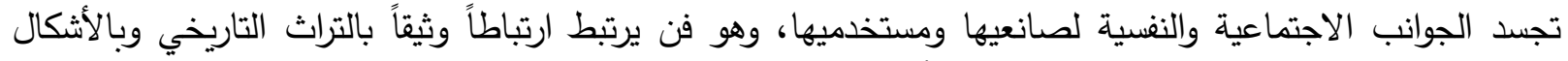
المرئية في بيئة الصانع المحيطة، بالإضافة إلى أن هذه المهنة ترتبط بالعادات والتقاليد الشعبية والاجتماعية.

والأشكال الفخارية في مصر امتداداً لحضارة مصر الطويلة وربما كانت الأشكال الفخارية الشعبية خلفية وراء ابتكارات

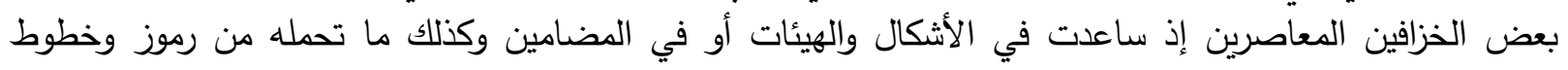
وهندسيات وتجريدات.

الأواني والمنتجات الثعبية الفخارية المرتبطة بمناسبات اجتماعية:

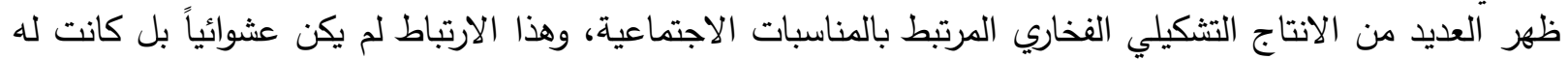

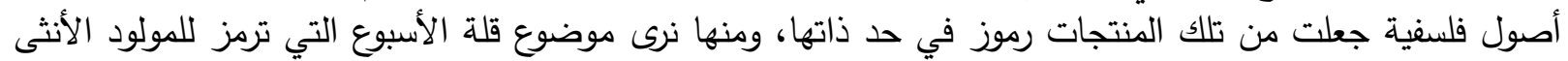

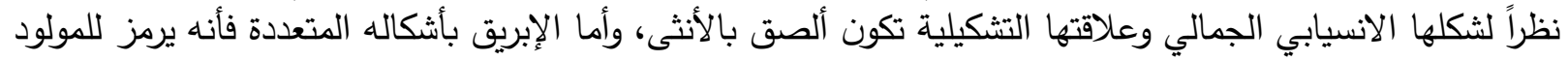

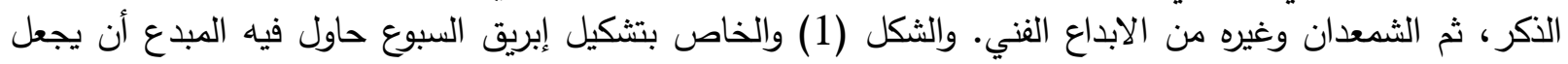

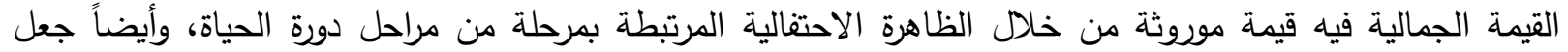

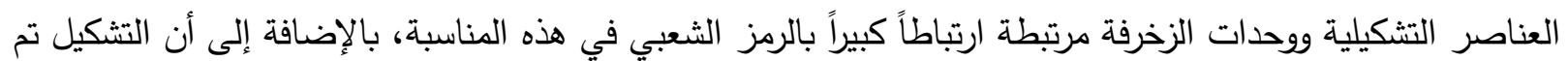

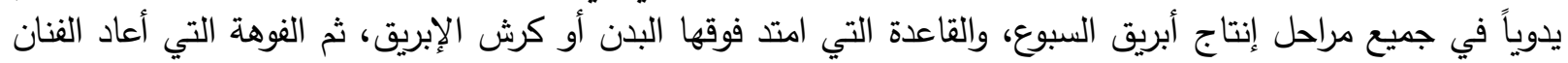
صياغتها بالثكل الذي يحقق فيه التوازن البصري، والتناغم الإيقاعي للبناء ككل.

ولأن التشكيل الفخاري في خصائصه تشكيلاً نحتياً، فإن المبدع في بناءه للشكل(2) اتخذ الرؤية الشعبية لحاملة الجرة

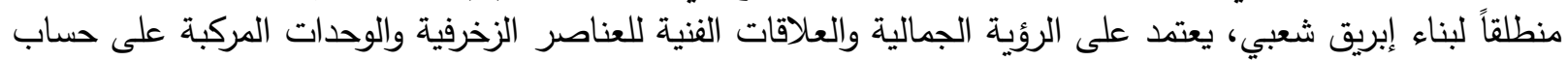

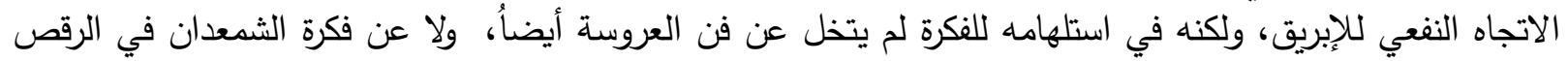

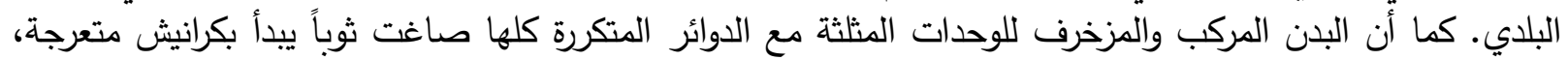
وينتهي أيضاً بنفس الكيفية، وحرص الفنان على بقاء أدق التفصيلات "العقد حول رقبة العروسة" وكذلك لجأ إلى تأكيد

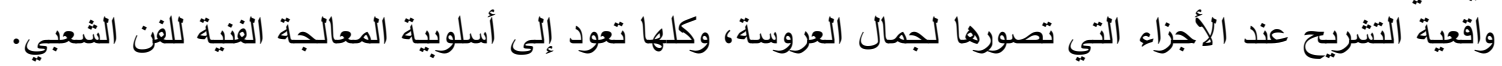
أما عن الشمعدان فنجد الفنان الشعبي انفعل به وعبر عنه بصيغ مختلفة، فنجد في الشكل (3) إن الفنان الشعبي لم

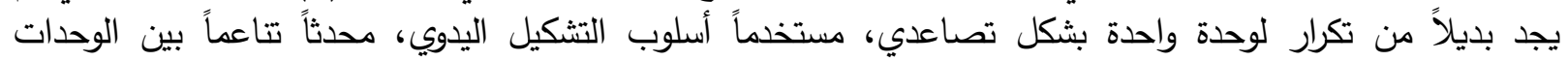

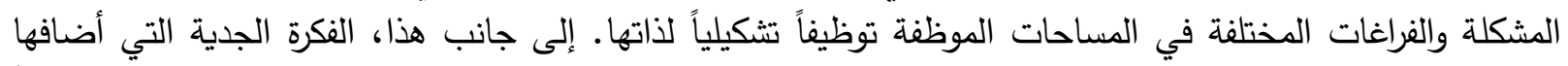

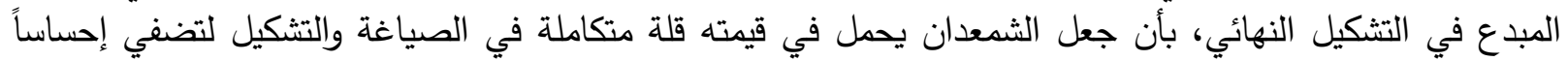

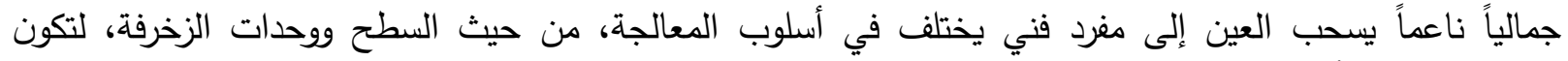
المحطة التي تهدأ فيها العين من التكتل الزخرفي الموجود في بدي بدن الثمعدان.

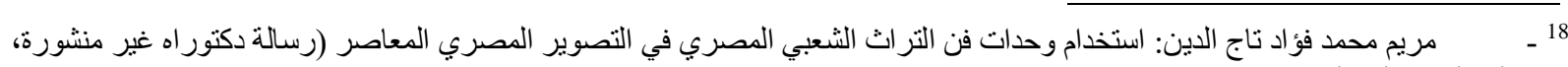

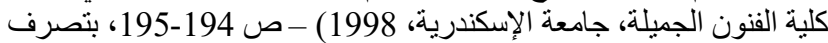

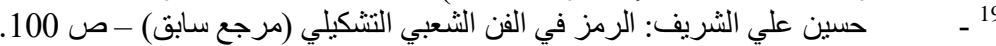


كما لاحظت الباحثة ميل الفنان الشعبي لإظهار براعته الفنية والإبداعية فكان أكثر ميلا للإنتاج الأشكال البنائية المركبة

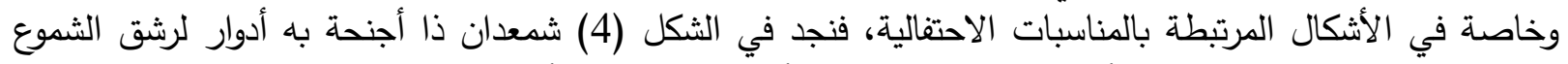

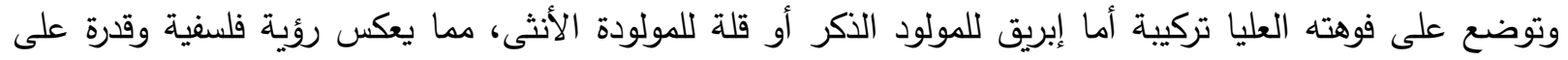
التوظيف لأدوات التشكيل بشكل واع.

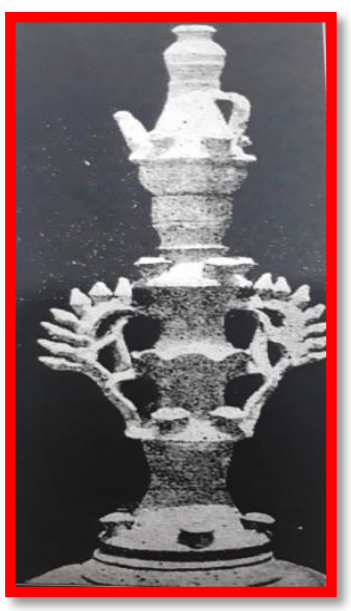

شكل (4) (4)

شمعدان ذو اجنحة يعلوه إبريق سبوع دو اجنة

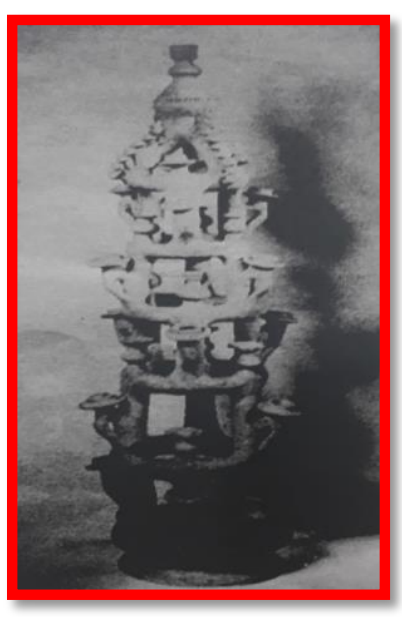

شكل (3) شعدان

شمعدان سبوع ذو هيئة تركيبية يعلوه قلة

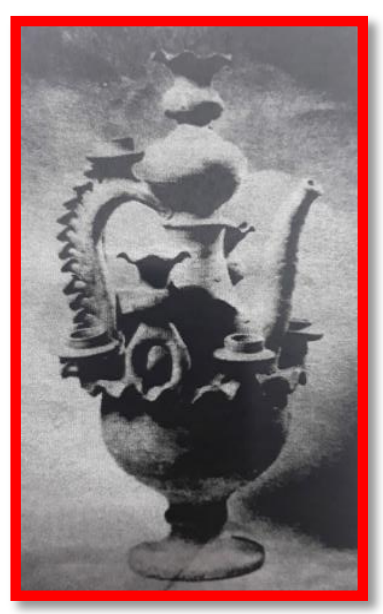

شكل (2)

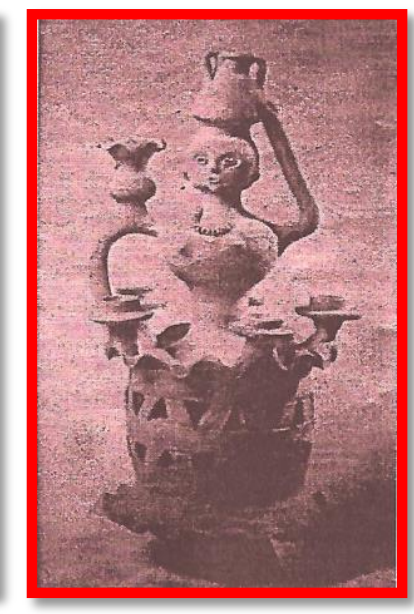

شكل (1)

- تثكيل يدوي نموذج من

عرائس الثمعدان الثعبي لدوي
أبريق سبوع من إن أن

الفخار

أخيراً ومن خلال تحليلنا لتلك الرموز الشعبية والمنحوتات والأواني الخزفية السابقة نستطيع استخلاص أن الدوائر

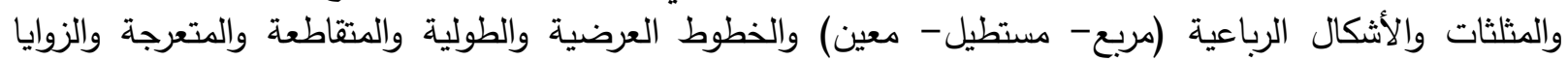

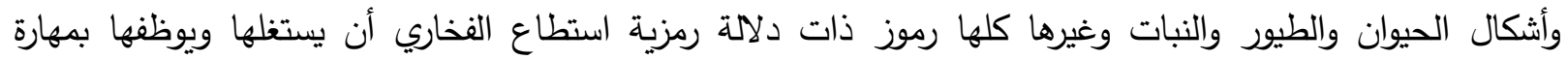

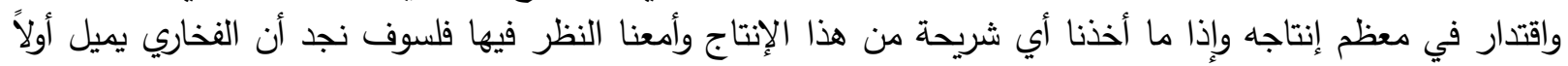

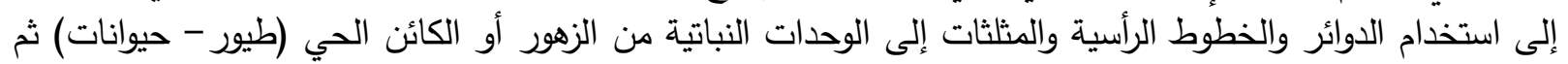

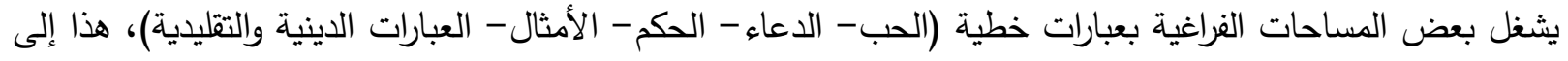
جانب اشكاله ومنحوتاته التركيبية البنائية التي جاء تتفيذها في نسق هنية التدسي متزن بالغ المرونة والطواعية في إحكام ذكي جميل.

كما ان فهمنا للبعد الرمزي للعناصر والزخارف الشعبية استطاع ان يفسر كيف أن الفخار وغيره من الحرف الشعبية

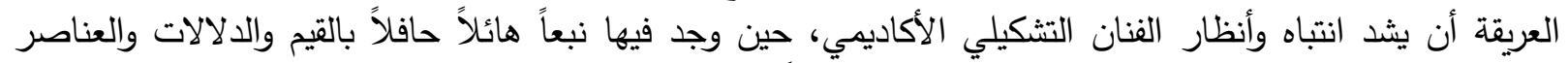

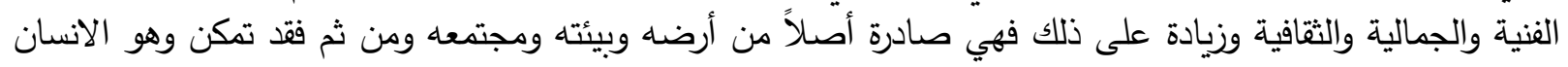

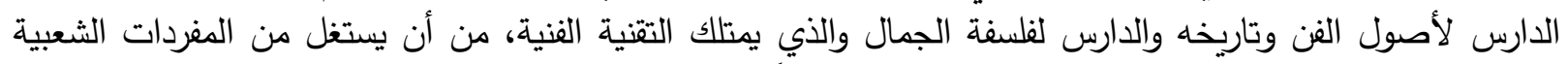

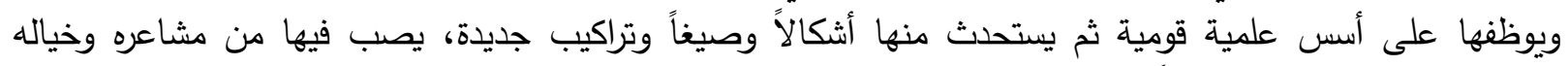

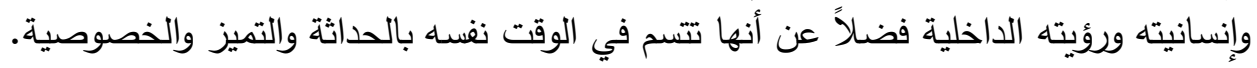

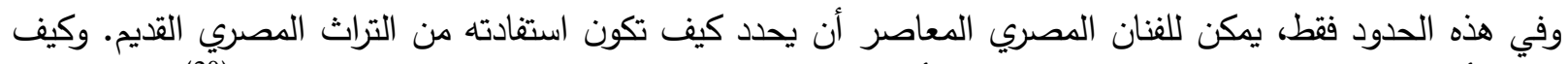
يظهر أثر هذه العناصر في طابعنا القومي، بعد أن تنصهر في بوتقة التكوين الكلي الزاخر بالمتغيرات. (20)

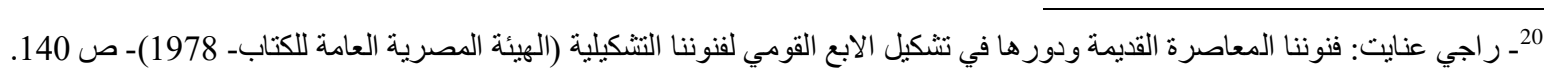


- - رفع مستوى الحرفي في كافة النواحي الصحية والاجتماعية والثقافية حتى يتم الاستفادة من ذلك في مستوى أعماله.

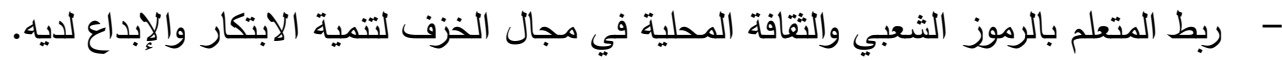
- - - استخدام خدمات محلية شعبية متوفرة وتتميز بانخفاض تكلفتها.

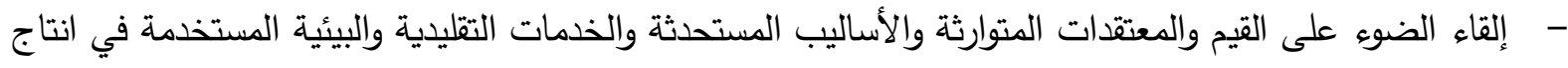

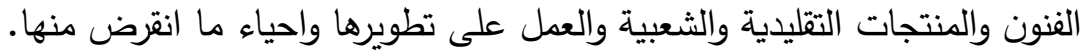

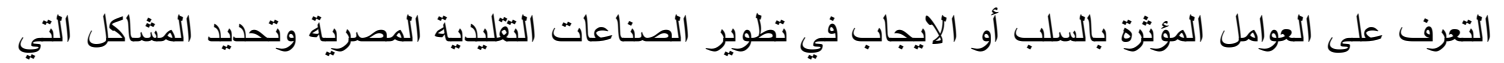
تعوق تطورها وانتشارها. مناقشة برامج تطوير وتحديث الصناعات التهات التقليدية ومتطلبات جودة منتجاته. - - التعريف بالمنتج التقليدي المصري وكيفية دعم قدراته التنافسية للتوافق مع المتغيرات العالمية وتوفير المعلومات

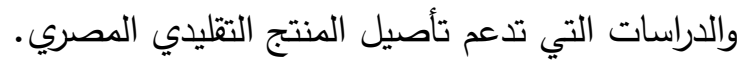
- - اقتراح البدائل التي تساعد على جذب جيل جديد من الصناع والحرفين للعمل في مجال الصناعات التقليدية التي كادت أن تنقرض. - إفراد بعض الدراسات التي تتناول مراكز التدريب الحرفي لإنتاج الخزف، ومناقشة هياكل وأساليب التدريب والتأثير البيئي والجغرافي على عمليات التدريب.

1- أكرم قانصو: المراجع: التصوير الثعبي العربي "سلسلة عالم المعرفة- المجلس الوطني للثقافة والفنون- الكويت" 1995م.

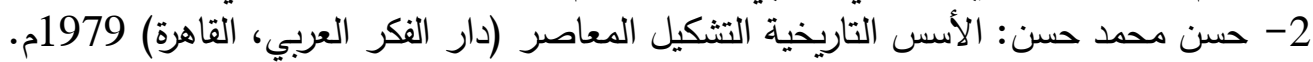

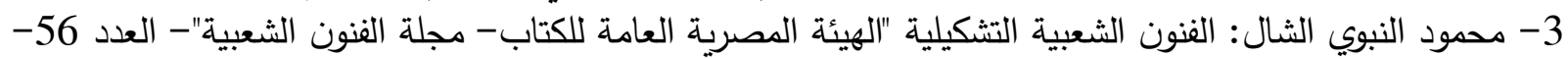
.1989

4- جدى منصور : الرمزية في الفن الحديث "وزارة الاعلام - عالم الفكر - المجلد السادس عشر - العدد الثالث 1985 الكويت.

5- أحمد أبو زيد: الرمز والأسطورة والبناء الاجتماعي "عالم الفكر ، المجلد السادس عشر" العدد الثالث.

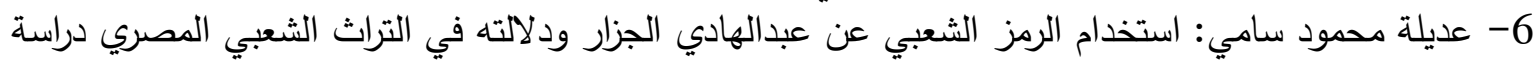

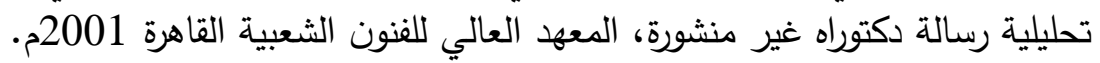
7- حسين علي الثريف: الرمز في الفن الثعبي التشكيلي "مجلة الفنون الثعبية الثقافية والإرشاد القومي" العدد الثاني ابريل 1965م. 8- مرفت حسين السويفي: اتجاهات الخزف المصري المعاصر "مطابع لوتس بالفجالة القاهرة 1995م.

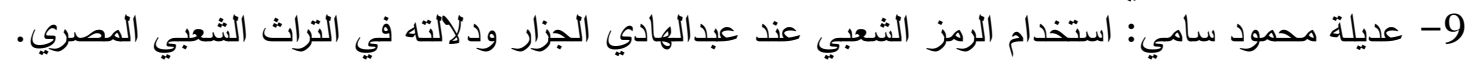

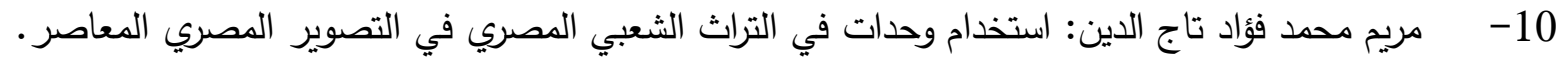

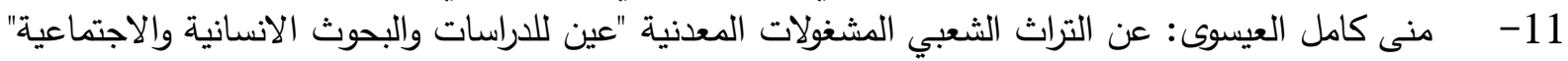

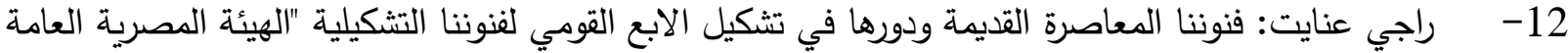
للكتاب 1978م" ماجي 